\title{
IJTIHAD UMAR BIN KHATTAB DAN RELEVANSINYA TERHADAP HUKUM ISLAM KONTEMPORER
}

\author{
QADRIANI ARIFUDDIN
}

(IAI DDI Polewali Mandar)

\begin{abstract}
ABSTRAK:
Tulisan ini mengkaji tipologi ijtihad Umar bin khattab dengan merelevansikannya dengan persoalan-persoalan di seputar hukum Islam dengan kehidupan kontemporer. Permaslahan pokok yang menjadi fokus kajian ini, bagaimana gambaran ketokohan Umra bin Khattab, dan bagaimana relevansi ijtihad Umar dalam di seputar hukum Islam kontemporer. Di samping itu, Tulisan ini disandarkan pada kajian melalui kajian pustaka dengan tujuan untuk mengetahui perspektif teoritis permasalahan ijtihad maupun aplikasi ijtihad yang digagas oleh Umar bin Khattab. Jenis tulisan yang diterapkan adalah histografi dengan menggambarkan ketokohan seorang sahabat Nabi yang dikenal kreatif dan inovatif dengan menggunakan pendekatan historis dan hukum. Lewat beberapa kajian literatur baik penilaian oleh seorang fakar maupun riwayat-riwayat yang menceritakan kehidupan sosio-politik Umar bin Khattab, ditemukan bahwa Umar adalah seorang sahabat Nabi yang paling kreatif dalam membagun gagasan-gagasan solutif terhadap permasalahan yang dihadapi oleh umat. Kolaborasi dari seorang pemimpin yang bijak, tegas dengan sikap kecendikiawanan yang dimiliki oleh Umar membuat sahabat-sahabat lain menjadikannya sebagai rujukan dalam berbagai persoalan keagamaan dan sosial-politik. Meski dalam ijtihad Umar terkadang tidak sejalan dengan semangat teks dan sunnah, namun Umar tetap berijtihad dalam kerangka keimanan. Beberapa contoh ijtihadnya yang mengedapankan kemaslahatan umat yang memiliki relevansi dalam hukum kontemporer antara lain: persamaan di depan hukum yang banyak ditiru oleh bangsabangsa yang sudah maju, kasus pencurian seorang pemuda yang oleh Umar tidak menjatuhkan hukuman kepada pemuda tersebut berdasarkan ijtihad dengan pertimbangan kemaslahatan, pembagian tanah rampasan perang yang diperintahkan oleh al-Qur'an secara tekstual dan dicontohkan oleh Nabi, namun lagi-lagi Umar tidak menjalankan perintah al-Qur'an dan sunnah berdasrkan ijtihadnya. Demikian pula lembaga al-hallu wal aqdhi yang digagas Umar yang kemudian berkembang yang dikenal sekarang lembaga legislatif dan parlemen.
\end{abstract}

Keywords: Ijtihad, Umar bin Khattab, Hukum Islam Kontemporer 


\section{A. Pendahuluan}

Adalah realitas yang tak dapat diingkari, bahwa kemajuan dan modernitas adalah bagian dari hukum sejarah yang tak bisa dielakkan dalam diskursus keagamaan kita. Mengingkarinya berarti menantang adanya hukum-hukum Tuhan yang bersifat realitas obyektif yang tidak bisa dihindari oleh siapapun. Agama yang diakui memiliki sumber epistimologi yakni al-Qur'an dan hadis harus rela menerima kenyataan-kenyataan yang terus mengalami perubahan. Namun kerelaan itu bukan berarti memenjarakan teksnya secara pasrah menghadapi kenyataan itu, melainkan dengan cara yang cerdas dalam mersespon perubahan-perubahan itu termasuk perubahan-perubahan yang ada di seputar persoalan-persoalan hukum.

Al-Qur'an dan hadis juga dipahami sebagai sumber hukum yang paling fundamental. Kedunya diakui sebagai sumber primer dalam menetapkan hukum sehingga ketika ada persoalan yang menyangkut problema yang berkaitan dengan persoalan-persoalan keagamaan termasuk persoalan hukum, maka segara dicari solusinya dengan merujuk kepada al-Qur'an dan hadis. namun demikian, al-Qur'an yang sebgaian ayat-ayatnya ada yang qath'i dan zanni, ada muhkamat dan mutasyabihat, mujmal sehingga dibutuhkan sebuah pendekatan dalam mengeksplorasi teks-teksnya agar dapat memahaminya dengan jelas. Sementara hadis itu sendiri memiliki fungsi terhadap al-Qur'an sebagai bayan tafsir, bayan ta'kid yang berfungsi untuk menjelaskan ayat-ayat al-Qur'an yang masih bersifat global maupun untuk menguatkan teks-teksnya.

Pada satu sisi, seiring dengan perkembangan situasi dan kondisi yang melingkupi alur sejarah kehidupan umat manusia, ada persoalan-persoalan yang kemungkinan tidak ditemukan secara eksplisit disinggung dalam al-Qur'an maupun hadis, maka disinilah gagasan inovasi dan dinamisasi pemikiran mendapatkan momentumnya sebagai upaya membangun dialektika antara teks dan realitas. Namun persentuhan teks dengan realitas jika mengalami kebuntuan dalam menetapkan hukum maka agama sangat menghargai pemikiran bahkan dianggap sebagai kerja kesalehan dengan cara melakukan metode ijtihad. Ini berarti bahwa berijtihad memiliki urgensi dalam wacana keagamaan kita.

Dalam konteks sejarah kehidupan sahabat, adalah Umar bin Khattab dianggap sahabat yang paling semangat dalam membangun gagasan inovatif di seputar persoalan keagamaan pada khususnya maupun persoalan-persoalan lain yang berkaitan dengan posisinya sebagai khalifah yang notabene-nya sebagai kepala pemerintahan dalam mengatur dan mengambil kebijakan roda pemerintahan. Umar dengan kapasitas intelektualitasnya yang cukup memadai seringkali memutuskan persoaanpersoalan yang tidak secara eksplisit disinggung dalam al-Qur'an maupun hadis bahkan terkadang berseberangan apa yang disinggung secara tekstual dalam al-Qur'an maupun Nabi sendiri.

Progresivitas pemikiran Umar dapat dianggap emberio munculnya 
intelektual dalam Islam yang hingga hari ini menjadi bagian terpenting dalam wacana keagamaan kita. Oleh karena itu mengkaji gagasan-gagasan Umar sebagai peletak dasar metode ijtihad dapat menjadi inspirasi guna merespon perubahan-perubahan yang semakin kompleks. di sinilah urgensinya kembali mendiskusikan tentang persoalan ijtihad Umar dengan mempermasalahkan apa saja yang terkait dengan persoalan ijtihad? bagaimana ijtihad Umar bin Khaththab kaitanya dengan persoalan hukum Islam kontemporer? persoalan-persoalan inilah yang akan menjadi maisteram dalam tulisan ini.

\section{B. Ijtihad Dan Problematikanya}

Menurut bahasa ijtihad berasal dari bahasa Arab. Asal kata dari ijtihad adalah jahada yang berarti berusaha dengan sunggug-sungguh. ${ }^{1}$ Ijtihad sewazan dengan ifta'ala yang bentuk masdarnya dari kata ijtahada yajtahidu yang bermakna mengerahkan segala kesanggupan untuk mengerjakan sesuatu yang sulit. Maka tidak tepat jika kata ijtihad digunakan untuk ungkapan "orang itu berijtihad dalam mengangkat kursi. Sebab mengangkat kursi adalah perbuatan mudah yang bisa dilakukan oleh siapapun.

Pengertian ijtihad secara bahasa tersebut berkaitan erat dengan pengertian nya secara terminologi. Dimana untuk melakukan ijitihad seseorang disyaratkan untuk memiliki kemampuan yang

1 Ahmad Warson al-Munawwir, Kamus al-Munawwir Arab-Indonesia Terlengkap (Yogyakarta: Pondok Pesantren al-munawwir, 1984), h. 234. mumpuni. Para pakar mendepenisikan ijtihad seperti dikutip oleh Saifuddin Shidik yaitu: " mencurahkan segala kemampuan untuk mengeluarkan hukum syara' dari nash (sumber hukum) yaitu alQur'an maupun hadis .2

Dalam kamus bahasa Indonesia, ijtihad adalah usaha sungguh-sungguh yang dilakukan para ahli agama untuk mencapai suatu putusan (simpulan) hukum syara, mengenai kasus yang penyelesaiannya belum tertera dalam alQur'an dan sunnah. ${ }^{3}$ bagi ulama yang berpikir holistik dan integral, ijtihad diartikan sebagai segala upaya yang dilakukan oleh para mujtahid dalam berbagai bidang ilmu,termasuk teologis, filsafat dan tasawuf. ${ }^{4}$ Bagi mereka tidak hanya terbatas pada aspek hukum. Depenisi ini lebih bersifat universal dan global tanpa menapikan ijtihad itu pada persoalan hukum saja. Hal ini sebangun dengan pandangan orientalis semacam B. Wael Hallaq yang banyak mengkaji di seputar persoalan hukum bahkan banyak pemikir Islam menjadikannya sebagai rujukan.

Dari pengertian ijtihad tersebut dapat diketahui bahwa dasar dalam melakukan ijtihad adalah al-Qur'an maupun hadis. Dengan kata lain al-Qur'an dan hadis sebagai rujukan dalam melakukan ijitihad ketika ada nash yang

\footnotetext{
${ }^{2}$ Saifuddin Shidik, Ushul Fiqhi (Jakarata: PT Intermedia Ciptanusantara, 2009), h. 54.

3 Team Pustaka Phoenix, Kamus Besar Bahasa Indonesia (Edisi Baru) ( Jakarta: Media Pustaka Phoenix, 2008), h. 342.

${ }^{4}$ Harun Nasution," Ijtihad Sumber Ketiga Ajaran Islam”, dalam Haidar Baqir, Ijtihad dalam Sorotan ( Bandung: Mizan, 1988), 108.
} 
secara implisit tidak jelas dasar hukumnya. Dalam konteks ini, dapat menjadi perhatian utama dalam melakukan ijtihad adalah ayat-ayat yang dianggap belum jelas yang dalam istilah ulumul Qur'an ayat-ayat yang bersifat zhanni (hipotetik) bukan yang ayat-ayat yang qath'i ( absolut).

\section{Argumentasi dalam Berijtihad}

Permasalahan ijtihad, bisa menimbulkan pertanyaan apakah ijtihad itu dapat dijadikan sebagai sumber hukum Islam? untuk menjawab persoalan ini, dapat dikemukakan beberapa pandangan disertai dengan argumentasinya. Ali Hasaballah misalnya berpendapat bahwa ijtihad merupakan sumber hukum yang ketiga dalam Islam, setelah al-Qur'an dan hadis. Argumentasi di atas dapat diperkuat dengan beberapa dalil seperti: riwayat yang yang menceritakan Nabi mengajar para sahabat berijtihad.

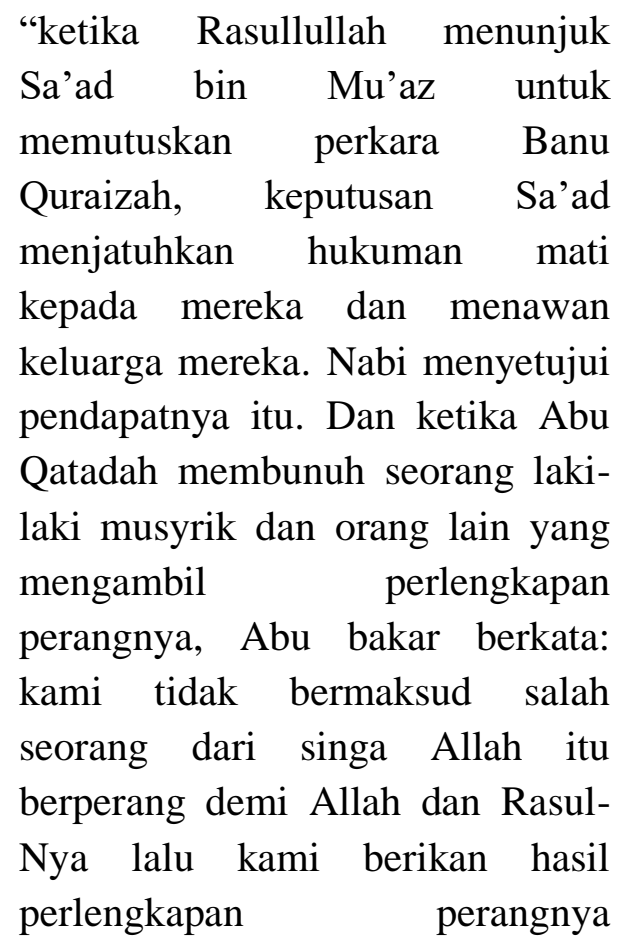

kepadamu. Kembalikanlah kepadanya perlengkapan korban itu. Rasulullah berkata: 'benar, kembalikan perlengkapan korban itu kepadanya. ${ }^{5}$

Demikian pula riwayat yang lain::

"diriwayatkan dari sekelompok penduduk Hams, sahabat Mu'az bin Jabal, bahwa Rasulullah saw, ketika bermaksud untuk menguitus Mu'az ke Yaman, beliau bertanya 'apabila dihadapkan kepadamu suatu kasus hukum, bagaimana anda memutuskannya? Mu'az menjawab: 'saya memutuskannya berdasarkan al-Qur'an. Nabi bertanya lagi, jika kasus itu tidak ditemukan dalam al-Qur'an?' Mu'az menjawab, saya akan memutuskannya berdasarkan sunnah Rasulullah. Lebih lanjut Nabi bertanya, jika kasusnya tidak terdapat dalam sunnah Rasul dan al-Qur'an? Mu'az menjawab:'aku akan berijtihad dengan seksama. Kemudian Rasulullah menepuk-nepuk dada Mu'az dengan tangannya, seraya berkata: 'segala puji bagi Allah yang telah memberikan petunjuk kepada utusan Rasulullah tethadap jalan yang diridhainya.

5 Muhammad Husain Haekal, al-Faruq Umar terjemah Ali Audah, Umar bin Khattab: Sebuah Telaah Mendalam Tentang Pertumbuhan Islam dan Kedaulatannya Masa itu Surabaya: (Litera AntarNusa, 2011), h. 684. 
Dengan menggunakan hadis di atas, ada ahli ushul piqhi yang berpendapat lain bahwa ijtihad bukan sumber hukum, melainkan sebagai metode penetapan hukum. ${ }^{6}$ Bagi kelompok ini, hadis tersebut mengisyaratkan bahwa sumber utama fiqhi adalah al-Qurt'an dan hadis . jika tidak ditemukan dalam alQur'an dan hadis, maka ijtihad diperbolehkan dengan tetap merujuk kepada al-Qur'an dan hadis. Sementara itu, kelompok yang disebutkan pertama memahami hadis itu sebagai petunjuk, bahwa ijtihad harus dijadikan sumber, ketika al-Qur'an dan hadis tidak menyebutnya secara eksplisit.

Terlepas dari apakah ijtihad itu bagian dari sumber atau bukan, yang jelas berijtihad menduduki posisi terpenting dan terhormat dalam konteks pemikiran Islam, bahkan Islam sangat menghargai orang yang memaksimalkan pemikirannya dengan menyandang gelar "ulul al-bab". Dalam hal ini Harun Nasution mengemukan bahwa al-Qur'an sangat menganjurkan kepada umat Islam untuk menggunakan akalnya. ${ }^{7}$ Oleh karena itu istilah ijtihad tidak dapat dipisahkan dari istilah ra'yu, istilah ini dapat dimaknai sebagai bagian dari upaya pencarian dan perenungan terhadap masalah-masalah tetentu berdasarkan al-Qur'an dan hadis atau prinsip-prinsip umum syariat Islam. ${ }^{8}$ Orang-orang yang memiliki kemampuan berpikir secara ilmiah dengan cara melakukan ijtihad, maka Nabi

\footnotetext{
${ }^{6}$ Haidar baqir, op.cit, h. 40.

${ }^{7}$ Harun Nasution, Akal dan wahyu dalam Islam ( Jakarta: UI Press, 1986), h. 39.

${ }^{8}$ Nadiyat Syarif, al-Ijtihad Fial-Islam ( Beirtut: Mu'assasat al-Risalat,1981), h. 35.
}

menghargai sebagai kerja kesalehan yang akan mendapatkan pahala. Seperti dalam sebuah riwayat yang mengatakan:

"Apabila seorang hakim berijtihad dan ijtihadnya itu benar maka akan mendapat dua pahala dan jika hasil ijtihadnya itu salah maka mendapat satu pahala".

Hadis tersebut mengisyaratkan pentingya ijtihad itu dilakukan jika guna untuk menyelesaikan perkara yang tidak disebutkan dalilnya secara eksplisit dalam al-Qur'an dan hadis. Kendati ijtihad itu tidak tepat maka ijtihad masih tetap dihargai sebagai bagian dari pahala. Dari logika ini, dapat dipertegas bahwa tidak selamanya produk pemikiran para mujtahid itu mutlak benar. Pendapat para mujtahid itu relatif yang masih perlu diuji kebenarannya. Paling tidak bisa dirujuk pandangan ahli ushul piqhi bahwa pendapat para mujtahid itu mendekati kebeanaran.

Syafi'i Ma'arif menilai sebuah keharusan dalam proses berijtihad dengan salah satu alasannnya adalah bahwa: pembahuruan yang sangat erat kaitannya dengan ijtihad. Pemikiran dan pelaksanaan ajaran Islam pernah ditunjukkan secara kreatif oleh generasi sahabat, terutama oleh khalifah Umar bin Khattab yang berani merubah kebijaksanaan Nabi tentang berbagai persoalan keagamaan maupun kemasyarakatan. ${ }^{9}$

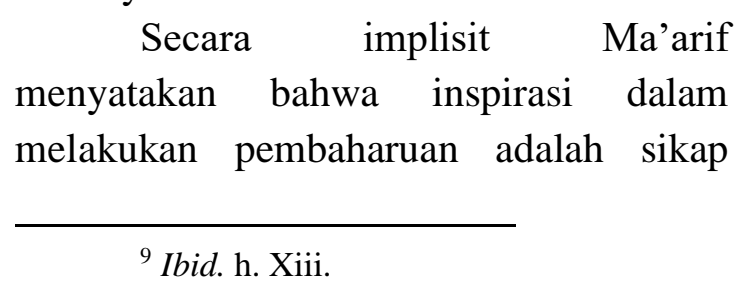


kreatif yang ditunjukkan oleh Umar Ibnu Ktattab. Apa yang telah dilakukan Umar memang banyak di kalangan cendikiawan yang menjadikan Umar sebagai topik kajian maupun penelitian karena dianggap bagian yang paling penting dan berjasa dalam membangun pemikiran Islam. kreatifitas Umar memang patut menjadi sumber inpirasi dalam setiap gerakan pembaharuan. Tidak sedikit reperensi yang menggambarkan Umar sebagai sahabat yang senang menggunakan rasionya dalam memahami persoalan keagamaan.

\section{Ijtihad dan Perubahan Sosial}

Salah satu agenda yang menjadi pusat perhatian umat Islam adalah merespon realitas sosial yang senantiasa mengalami perubahan. Sementara pada sisi lain agama yang sifatnya absolut harus berhadapan dengan realitas yang sifatnya relatif yang dinamis. Menghadapi kenyataan tersebut, umat Islam dituntut untuk memahami agamanya secara cerdas dan kreatif. Salah satu dari sikap kreatif itu adalah berijtihad. Namun pada sisi lain tak sedikit kaum muslimin memiliki pandangan yang sempit bahwa hasil ijtihad para ulama terdahulu, yang merupakan penafsiran atas al-Qur'an bernilai mutlak benar dan absolut. Penomena inilah dalam pandangan Harun Nasution, menimbulkan dogmatisme yang ketat, pandangan sempit dan ketidakterbukaan terhadap hal-hal yang baru. Perubahan-perubahan yang dibawa oleh kemajuan ilmu pengetahuan dan teknologi dicap sebagai bid'ah, inovasi yang tidak sejalan, bahkan bertentangan dengan agama. ${ }^{10}$ Padahal masyarakat senantiasa mengalami perubahan. Perubahan masyarakat dapat berupa perubahan tatanan sosial, budaya, sosial ekonomi dan lain-lainnya. Harun Nasution mengamati perkembangan bahasa seperti dikutip Fathurrahman Djamil dari para ahli linguistik dan semantik, bahasa akan mengalami perubahan setiap sembilan puluh tahun, perubahan dalam bahasa, secara langsung atau tidak langsung, mengandung arti perubahan dalam masyarakat itu. ${ }^{11}$ Dalam konteks ini, relevan untuk mengutip pernyataan Rasullullah saw, bahwa setiap seratus tahun (seabad) akan ada orang yang bertugas memperbaharui pemahaman keagamaan. ${ }^{12}$ Agaknya, pernyataan Nabi itu sejalan dengan hasil penelitian para ahli linguistik dan semantik.

Pernyataan Nabi di atas sepertinya perubahan adalah yang mesti terjadi di alam semesta ini yang harus disikapi juga dengan perubahan pola pikir. Masa lalu dan masa sekarang tentu berbeda, sebab setiap anak generasi adalah bagian dari anak zamannya. Oleh karena itu orang juga harus menyelasaikan masalah sesuai dengan konteks sejarahnya. Cara berijtihad juga tidak terlepas dari tuntutan dan kebutuhan msyarakat berdasarkan kemaslahatan umat.

10 Harun Nasutiondan Azyumardi Azra (Ed), Perkembagan Modern dalam Islam ( Jakarta: yayasan Obor Indonesia, 1985), h. 1.

${ }^{11}$ Fathurrahman Djamil, Metode Ijtihad Majlis Tarjih Muhammadiyyah ( Jakarta: Logos, 1995), h. 28.

${ }^{12}$ Lihat Abu Dawud, Sunan Abu Dawud ( tt. Dar al-fikr, t.th), 109. 
Dalam konteks sejarah, proses pembaharuan dan ijtihad telah pernah dirintis semacam ibnu Taimiyyah seorang bapak modernis. Program utama Ibnu Taimiyyah ialah penegasan kembali tentang syari'ah dan pembelaan terhadap nilai-nilai agama yang telah dirusak. Bagi Ibnu taimiyyah, syari'ah adalah sebuah prinsip agama yang lengkap, meliputi kebenaran spritual kaum sufi, kebenaran rasional bagi kaum filosof dan teolog, serta meliputi masalah hukum. ${ }^{13}$

Untuk memahami nilai-nilai dan jaran-ajaran agama secara benar, ibnu Taimiyyah menghimbau kaum muslimin untuk mencari kembali ajaran-ajaran Islam yang sejati dan untuk melakukan ijtihad dalam menafsirkan doktrin-doktrin agama. Ibnu Taimiyyah bahkan menyatakan dirinya sebagai seorang mujtahid $^{14}$ mutlaq. Oleh karena itu gerakan pembaharuan yang muncul pada beberapa abad kemudian tidak dapat

13 Ahmad Syafi'i Ma'arif, ( pengantar) dalam Fathurrahman Djamil, Metode ijtihad Majlis Tarjih Muhammadiyyah ( Jakarta: Katalog dalamTerbitan, 1995), h. Xii.

${ }^{14}$ Orang yang berijtihad disebut mujtahid. Dalam kajian hukum Islam,orang yang berijtihad atau mujtahid memilki beberapa tingkata: a) Mujtahid fi al-syar'i,disebut juga mujtahi mustaqil.yaitu orang yang membangun suatu mazhab seperti imam mujtahid yang empat yaitu imam Abu hanifah, Malki, Syaf'i dan Ahmad bin Hanbal. B) Mujtahid fi al-mazhab, yaitu mujtahid yang tidak membentukmazhab sendiri tapi mengikuti salah seorang imam mazhab. Mujtahid fi al-mazhab terkadang menyalahi ijtihad imamnya pada beberapa masalah. C) Mujtahid fi al-masail ialah mujtahid yang berijtihad hanya pada beberapa masalah dan bukan pada masalahmasalah yang umum. c) mujtahid muqayyad.yaitu mujtahid yang mengikat diri dengan pemdapat salaf dan mengikuti ijtihad mereka. Saifuddin Shidik, Op.cit., h. 56 dilepaskan dari pengaruh Ibnu Taimiyyah. ${ }^{15}$

Amin Rais juga mengamati situasi dewasa ini bahwa perubahan sosial sangat cepat dan di sana sini menimbulkan pergeseran nilai-nilai. Menurut Amin Rais, bila kita tidak cepat mengantisipasi perubahan sosial itu dan sekaligus mencari arahan yang tepat, tidak mustahil Islam akan mengalami "crisis of relevance" atau krisis relevan. Amin menambahkan, menjadi tugas kaum ulama dan cerdik-cendikia serta para memimpin umat Islam untuk terus berpikir keras, memecahkan berbagai masalah yang terus bermunculan secara multikompleks. Semuanya akan berpulang pada sejauh mana kesungguhan kita dalam meresponi tantangan-tantangan itu. ${ }^{16}$

Yang jelas menyikapi perubahan sosial yang terus berdialektik dengan wacana keagamaan kita, kita ditutut untuk mengikuti jejak-jejak apa yang telah pernah dirintis oleh Umar agar Islam mampu mengahadapi berbagai tantangan baik tantangan intelektual maupun spritual. Dinamika kehidupan yang terus bergerak mengikuti hukum sejarah (sunnatullah) adalah sesuatu yang tidak bisa dielakkan. Urgensi untuk membangun gairah berpikir dengan cara berijtihad dalam konteks ruang dan waktu. Re-interpretasi bahkan dekonstruksi terhadap ajaran agama yang sudah tidak relevan dengan perubahan sosial adalah kerja ijithad yang sangat

\section{${ }^{15}$ Ahmad Syaf'i Ma'arif, Loc.cit. \\ 16 Amin Rais ( Pengantar) dalam} Fathurrahman Djamil, Metode Ijtihad Majlis Tarjih Muhammadiyyah ( Jakarta: Logos, 1995), h. $\mathrm{X}$. 
strategis untuk membumikan doktrin agama yang lebih kontekstual yang tentu saja dalam hal ini penafsiran yang tidak terlepas dari substansi dan tujuan disyariatkannya agama itu sendiri yaitu kemaslahatan kemanusiaan universal.

\section{E. Ijtihad Umar Bin Khaththab: Potret Cendikiawan Sahabat Nabi}

\section{Nurcholish}

Madjid menggambarkan bahwa di antara para sahabat Nabi nampaknya tidak ada yang lebih bergairah kepada al-Qur'an dan teguh berpegang kepadanya seperti Umar bin Khttab, yang oleh Nabi semasa hidupnya pernah disebut sebagai seorang yang paling mungkin menjadi utusan Tuhan seandainya Nabi sendiri bukanlah Rasul Allah. Sejarah mencatat bahwa Umar adalah seorang sahabat Nabi, yang sekali pun sangat hormat kepada Nabi, namun tidak segan-segan mengajukan keberatan kepada gagasan atau tindakan Nabi jika dirasa olehnya bahwa Nabi berpikir atau bertindak atas kemauan sendiri, bukan atas petunjuk langsung Tuhan. ${ }^{17}$

17 Dalam ilmu tafsir diketahui tentang adanya beberapa ayat suci yang turun tidak mendukung gagasan Nabi tersebut, melainkan Umar. Umar sendiri adalah mantan salah seorang musuh Nabi yang paling keras, dan menjadi muslim hanya gara-gara suatu kali mendengar ayat-ayat suci dibaca oleh adik perempuannya yang telah lebih dahulu menjadi muslimah. Dan dalam hidup selanjutnya, Umar dikenal sebagai sahabat Nabi dan pemimpin kaum muslimin yang sangat dekat dengan kalangan al-Qurra' dan alHuffazd ( para ahli baca dan penghafal alQur'an). Lihat Nurcholish Madjid (editor) Khazanah Intelektual Islam ( Jakarta: Bulan Bintang, 1994), h. 3-4.
Karena ide-ide kreatifnya Umar diakui, baik oleh para sarjana Muslim sendiri maupun kalangan bukan Muslim, bahwa ia adalah orang kedua sesudah Nabi Muhammad saw. sendiri, yang paling menentukan jalannya sejarah Islam.tetapi juga karena semangat ivovatifnya itu. Michael H. Hart menilai Dalam konteks pemikiran Islam, pertamatama harus dilihat kembali masa para sahabat. Dari sana terlihat bahwa sahabat Nabi yang paling kreatif dalam berpikir adalah tokoh yang kemudian menjadi khalifah kedua yaitu Umar bin Khattab. ${ }^{18}$ Boleh dikata bahwa, dari sudut peninjauan yang menyeluruh, masa Umar adalah masa keemasan sejarah Islam. Maka tidak mengherankan kiranya bahwa pada zaman mutakhir ini, bilamana aspiran reformasi keagamaan, sosial dan politik Islam harus mencari model klasik bagi wawasannya, ia akan dengan bersemangat dan penuh simpati menyebut masa Umar. Golongan pemikir Islam modernis misalnya, sangat mengagumi Umar tidak saja karena ia meneladani bagaimana menagkap semangat Islam secara universal, tetapi juga karena ia berhasil menciptakan masyarakat yang menurut jargon-jargon modern tentunya akan dinamakan demokratis dan sosalistis. ${ }^{19}$

Sebangun dengan penilaian di atas, Muhammad Husain Haikal juga meggambarkan bagaimana pengaruh kecendikiawanan Umar dalam perkembangan sosial khususnya

${ }^{18}$ Michael H. Hart, Seratus Tokoh yang Paling Berpengaruh dalam Sejarah, terjemah H. Mahbub Djunaidi, ( Jakarta: Pustaka Jaya, 1987), h. 264.

${ }^{19}$ Ibid. h. 6. 
masyarakat Islam dan Arab pada saat itu. Umar sudah demikian rupa mengadakan ijtihad dalam bidang fikih, dalam bidang politik, ekonomi dan sosial dengan pengaruh yang begitu besar dalam masyarakat Islam dan masyarakat Arab semua, baik yang tinggal di semenanjung atau yang kemudian bermukim di negerinegeri yang sudah dibebaskan. Haekal juga menilai bahwa pada masanya, ijtihadnya pulalah yang menyelamatkan kehidupan sosial dari kemunduran. Dialah yang menjaga kehormatan jiwa Islam dalam hati kaum muslimin di manpun mereka berada.jasa Umar dalam hal ini besar sekali ditambah dengan sifat adilnya dalam menjalankan hukum serta kemampuannnya yang begitu memadai. ${ }^{20}$

Dalam kalangan sahabat sering terjadi proses dialektik dalam hal perbedaan pendapat. Hal ini pernah terjadi antara Umar dan Abu Ubaidah sekitar persoalan takdir. Yang satu didukung oleh Abu Ubaida dan kelompok muslim yang sependapat dengan dia, dan yang satu lagi didukung oleh Umar dan kelompok muslim yang sependapat pula dengan dia. Kedua belah pihak, masingmasing dengan keyakinannya, bahwa ia mempunyai kebebasan penuh untuk tetap berpegang pada pendapatnya, dan dalam waktu yang sama ia menghormati pendapat orang lain.

Kebebasan intelektual dan apa yang mereka praktekkan dengan saling menghormati antara umat muslimin dahulu itu merupakan unsur kekuatan mereka. Mereka yakin bahwa setiap

\footnotetext{
${ }^{20}$ Muhammad Husain Haikal, Op.cit., h.
} 659. pendapat orang dapat menyampaikan pendapatnya dengan tujuan demi kebaikan orang banyak, dan yang mereka cari ialah kebenaran demi Allah swt.

Ada yang menilai dari perbedaan pendapat itu adalah pendapat Umar yang dinilai tepat yang sesuai dengan ajaran determinsme ilmiah seperti yang diketahu dewasa ini, dan sudah diketahui oleh para filosof Yunani sejak lebih dari dua ribu tahun silam. Perbedaan pendapat Umar dengan sahabat yang lain tidak menghalangi Umar untuk tetap memperlihatkan sikap kecendikiwanananya dalam menyelesaikan berbagai persoalan kegamaan maupun persoalan sosial yang dapat mengancam umat. ${ }^{21}$

Para ahli hadis meriwayatkan berbagai peristiwa ketika ijtihad Nabi berbeda dengan ijtihad Umar, dan Allah membenarkan ijtihad Umar, Nabi menginginkan agar para tawanan Badar dibebaskan dengan tebusan, sedangkan Umar mengusulkan untuk membunuh mereka, Nabi hendak menshalatkan Abdullah Bin Ubayy, tapi Umar melarangnya. Dalam kasus-kasus ini,wahyu selalu turun membenarkan Umar. Nabi juga pernah menangis terisakisak menyesali kekeliruan ijtihadnya, disertai Abu bakar. Umar bertanya," Apa yang menyebabkan Anda dan sahabat Anda menangis? Kalau ada sesuatu yang patut aku tangisi, aku akan menagis. Kalau tidak ada tangisan, aku akan berupaya menangis seperti tangisan anda. “ Nabi kemudian menceritakan tentang

\footnotetext{
${ }^{21}$ Muhammad Husain Haeikal, Op.cit., h.
} 150 
wahyu yang membenarkan Umar dan menyalahkan Nabi. "Seandainya azab turun." Kata Nabi, “ tidak ada yang selamat kecuali Umar. ${ }^{22}$

Karena Umar adalah primadona dari kelompok pertama para sahabat ini, kemudian ada yang menyebut mazhab pemikiran mereka sebagai mazhab Umari. Sebagai lawan mereka dalam pemikiran mazhab Alawi, yang terdiri atas sahabatsahabat yang berkumpul di sekitar Ali bin abi Thalib. Umar pernah berkata" inilah ra'yu Umar. Kalau benar, dari Allah dan kalau salah, dari Umar. ${ }^{23}$

Penilaian-penilaian dan riwayat

yang dialamatkan kempada Umar, memang patutlah sejarah mencatat sebagai tokoh yang paling patut menjadi contoh untuk menyelesaikan setiap permasalahan yang dihadapi oleh umat, baik ulama maupun umara karena keduanya melekat pada diri seorang Umar.

\section{F. Ijtihad Umar dan Relevansinya Dalam Hukum Islam Kontemporer: Beberapa Kasus Gambaran}

Menurut Husain Haekal, hukum Islam sangat berhutang budi kepada ijtihad Umar, yang tidak kurang dari politik Islam dalam menegakkan kedaulatan, dengan pandangannya yang begitu progresif, disertai iman yang kuat dan keteguhan hatinya. Ia telah memantapkan prinsip-prinsip dan

22 Jalaluddin Rahmat (pengantar) dalamTaufik Adnan Amal, Islam dan Tantangan Modernitas: Studi atas Pemikiran Hukum Fazlur Rahman ( Bandung: Mizan, 1989), h.18.

${ }^{23}$ Ibid. pandangan-pandangannya dalam hukum piqhi, oleh mereka yang datang kemudian telah dijadikan pegangan, dan segala yang berasal dari dia dipandang sebagai bukti sahih. Tidak sedikit dari pengaruh prinsipprinsip itu yang penting sekali konsrtibusinya. Karenanya, penerapannya tetap berlaku sampai sekarang.

Dalam beberapa bidang hukum, baik dalam hukum Islam atau di luar hukum Islam sudah dianggap sebagai prinsip-prinsip universal yang sudah tak dapat dibantah lagi. Diantara prinsipprinsip itu ialah soal hukum darurat (terpaksa). Dalam al-Qur'an sudah ditentukan hukum-hukum Allah yang berlaku mengenai pembunuhan, pencurian, zina, tuduhan palsu dan perampokan. Dalam al-Qur'an disinggung "Barang siapa tidak memutuskan perkara menurut apa yang diturunkan Allah mereka itulah orang fasik. ${ }^{24}$ Namun demikian Umar justru terkadang tidak sejalan dengan tekstual ayat tersebut berdasarkan hukum darurat. Argumentasi Umar berdasarkan al-Qur'an 'jika dalam keadaan darurat (terpaksa) bukan sengaja hendak melanggar atau mau melanggar batas maka tidaklah ia berdosa. Allah maha pengampun dan maha Pengasih. ${ }^{25}$

Salah satu persoalan pidana yang disinggung secara tekstual dalam alQur'an adalah: "laki-laki dan perempuan yang mencuri, potonglah tangan keduanya. “26 secara tekstual ayat tersebut diperintahkan untuk menghukum para pelaku pencurian laki-laki maupun

\footnotetext{
${ }^{24}$ QS: al-maidah/5: 47.

${ }^{25}$ QS: al-baqarah/2: 173.

${ }^{26}$ QS. Al-Maidah/ 5: 48.
} 
perempuan. Kasus ini pernah terjadi pada masa Umar. ${ }^{27}$ Namun Umar justru tidak menjatuhkan hukuman pada pelaku pencuri tersebut dengan alasan yang berkaitan dengan memperlakukan kaidah ihtihsan yaitu beralihkanya hukum umum kepada hukum khusus. ${ }^{28}$ Artinya bahwa nash yang bersifat umum yang dapat menetapkan hukum suatu masalah dalam keadaan tertentu, hukum tersebut tidak dapat diterapkan karena adanya sebab maka berlakulah dalil yang khusus. Pada saat itu terjadi musim paceklik dan kemarau sehingga menimbulkan banyak yang kelaparan.

Nurcholish Madjid juga menggambarkan contoh klasik atas tindakan Umar yang mempertimbangkan kepentingan umum dalam menangkap semangat agama berkenaan dengan

27 Dalam sebuah riwayat bahwa ada sekelomopk pemuda pembantu-pembantu Hatib bin Abi Balta'ah mencuri seekor unta milik orang dari Muzainah. Ketika dibawa kepada Umar mereka mengaku.kusayyir bin as-Salt meminta agar mereka dijatuhi hukuman potong tangan. Setelah pergi ia dipanggil kembali lalu bertanya: sungguh kalau tidak karena saya tahu kalian memamfaatkan mereka dan membuat mereka kelaparan sehingga jika sekiranya ada dari mereka yang memakan makanan yang diharamkan oleh Allah mereka halalkan, niscaya saya potong tangan mereka. Kemudian ia menunjukkan kata-katanya kepada Abdul Rahman bin Hatib bin Abi Balta'ah dengan katanya: demi Allah, kalau saya tidak melakukan itu pasti saya denda kalian dengan denda yang sangat menyakitkan anda! Setelah itu katanya lagi: hai orang Muzainah (pemilik unta), berapa Anda hargai unta Anda itu? Empat ratus, Umar berkata kepada Abdur Rahman: pergilah dan berikan kepadanya delapan ratus, dan bebaskan anak-anak muda pencuri itu dari tuduhan pencurian, sebab hatib yang telah memaksa mereka mencuri, mereka dalam kelaparan dan mereka sekedar hidup. Muhammad Husain Haekal, Op.cit, h. 704.

28 Saifuddin Shidik, Op.cit., h. 62.. masalah tanah-tanah pertanian beserta garapan-garapannya yang barudibebaskan oleh tentara Muslim di negeri Syam. Pendirian Umar untuk mendahulukan pertimbangan tentang kepentingan umum yang menyeluruh, baik secara ruang ( meliputi semua orang di semua tempat maupun waktu mencakup generasi sekarang dan masa datang. Dalam masalah harta rampasan Umar berbeda pendapat dengan sahabat yang lain. ${ }^{29}$

Pertimbangan Umar tersebut mendapat bantahan dari sahabat lain yang tidak sependapat dengannya. Terjadi sebuah musyawarah dan dialog, namun Umar tetap pada pendiriannya sehingga karena sengitnya perdebatan itu sampai sahabat yang lain menuduh Umar telah melakukan kezdaliman yang dalam pendapatnya itu ia tidak berpegang pada Qur'an secara tekstual dan Sunnah Nabi yang sudah ada contohnya dari Rasulullah, tetapi kemaslahatan umum bagi negara dan poloitiknya itulah yang dijadikan dasar.jadi itu semata-mata pendapat Umar, dari hasil ijtihadnya, dan untuk memperkuatnya ia mengemukakakn

29 Sahabat Nabi yang menantang Umar dipeloporioleh Abdur Rahman Bin Auf dan Bilal. Mereka berpegang teguh kepada beberapa ketentuan lahir di beberapa tempat dalam alqur'an dan dalam Sunnah atau praktek nabi pada peristiwa pembebasan Khaybar (sebuah kata qase beberapa ratus kilometer antara Madinah), dari kelompok orang yahudi yang berkhianat. Tetapi, sebaliknya, sejak dari semula para sahabat Nabi yang lain, termasuk tokoh-tokoh sepertiUsman bin Affan dan Ali Bin Abi Thalib,sepenuhnya menyetujui pendapat Umar dan sepenuhnya mendukung pelaksanaannya. Nurcholish Madjid, Islam Doktrin dan Peradaban: Sebuah Telaah kritis Tentang Masalah Keimanan, Kemanusiaan dan Kemoderenan ( Jakarta: Paramadina, 1992),h. 391. 
argumen-argumen yang membuat Usman dan Ali dan sahabat yang lain yang mendengar argumennya itu pun mengatakan: " terserah kepada pendapat anda. Pendapat dan apa yang anda katakana itulah yang paling tepat. ${ }^{30}$

Diantara prinsip-prinsip hukum yang digagas oleh Umar yang sangat relevan dalam konteks kekinian bahkan kebanyakan negara yang sudah maju masih tetap kontektual adalah prinsip persamaan di depan hukum. Dia menulis hal itu kepada Abu Musa al-Asyari dan hakim-hakim yang lain seperti yang sudah kita lihat dan dia sendirian dilaksanakannya dengan sangat teliti. Dalam hal ini contoh yang cukup menonjol kasus Jabalah bin al-Aiham alGassani dengan cerita ini ialah yang telah terjadi ketika ada orang Yahudi mengadukan Ali bin Abi Thalib kepada Umar sedang kedudukan Ali terhadap Nabi di mata kaum muslimin umumnya sudah sama-sama kita ketahui. Tetapi ia berkata kepada Ali: Abul Hasan, duduklah berhadapan dengan lawanmu itu atau berkata: perlakukan samalah lawan anda itu Ali menyamakan dirinya dan duduk berhadapan dengan lawannya itu dengan menampakkan muka kesal. Sesudah perkaranya selesai Umar berkata: Ali rupanya anda tidak senang duduk berhadapan dengan lawan anda? Setelah itu ada sumber yang menyebutkan bahwa Ali menjawab tidak, tetapi saya tidak senang karena anda tidak mempersamakan ketika anda memanggil saya dengan Abul Hasan maksudnya sebutan itu

\footnotetext{
${ }^{30}$ Muhammad Husain Heikal, Op.cit., h.
}

memperlihatkan penghormatan kepadanya kata-kata Ali ini tidak menapikan bahwa Umar sangat menjaga adanya persamaan semua orang di depan hukum dan dia melihat bahwa persamaan ini merupakan syarat keadilan yang pertama lepas dari soal penilaian hakim sendiri suka atau tidak suka terhadap salah satu pihak yang berperkara. $^{31}$

Riwayat tersebut menggambarkan betapa Umar telah membangun prinsip persamaan di depan hukum tanpa pandang buluh meskipun orang yang paling terdekat dengan Rasulullah. Prinsip persamaan di depan hukum adalah bagian dari ijtihad dalam hukum (yurispondensi). Apa yang telah digagas oleh Umar adalah banyak negara yang mencontoh bangsabangsa yang telah berupaya untuk menegakkan prinsip persamaan di depan hukum, yang pada bangsa-bangsa lain baru terwujud pada waktu-waktu belakang saja.

Hal ini terbukti beberapa keistimewaan yang diberikan kepada orang-orang asing dalam legislasi dan hukum dalam imperium Usmani sampai waktu belakangan ini, dan apa yang masih berlaku di Mesir sampai akhirnya habis sama sekali-agar dapat kita lihat apa yang dilakukan Umar itu sepenuhnya adalah yurispondensi dan sepenuhnya ijtihad. Di samping it, beberapa revolusi yang terjadi di Eropa, dalam abad ke-18- dan ke-19, tak lain tujuan pertamanya adalah hendak mewujudkan adanya persamaan di mata hukum dan pengadilan, dan bahwa prinsip persamaan itu merupakan prinsip pertama yang ditetapkan oleh revolusi perancis dan

${ }^{31}$ Ibid. h. 705. 
diperkuat oleh piagam hak asasi manusia. ${ }^{32}$ Tentu tidak diragukan lagi bahwa prinsip inilah yang diusahakan oleh Umar dari dasar hukum Islam.

Dalam konteks hukum tata negara ada lembaga al-hallu wa al-aqdhi yang pada mulanya lahir dari gagasan Umar Bin Khattab yang terdiri dari sahabat yang dipandang ahli dan berpengaruh, yang tugasnya adalah memusyawarahkan berbagai masalah yang berkaitan dengan kemalahatan umum, terutama untuk mengambil keputusan-keputusan tentang kasus-kasus yang belum ada pada zaman Nabi. ${ }^{33}$ Inisiatif progresif Umar membentuk lembaga tersebut dalam situasi krusial pasca meninggalnya Nabi, Umar langsung melakukan tindakan menurut loginya sendiri yang dapat menyelesaikan masalah keumatan terutama dalam hal kepemimpinan, siapa yang akan menggantikan Nabi. Dari realitas sejarah ini sudah tergambar bahwa memang Umar sudah mulai memikirkan dan menanam pondasi bagaimana kita menjalankan pemerintahan secara demokratis dengan jalan memusyawarahkan setiap masalah yang dihadapi oleh rakyat. Lembaga ini kemudian berkembang menjadi sebuah lembaga yang cukup terhormat yang salah satu tugasnya untuk membuat undangundang. Lembaga ini biasa disebut sebagai lembaga legislatif atau parlemen.

\section{G. Penutup}

32 Ibid.

33 Dawan Raharjo, Ensiklopedi AlQur'an: Tafsir Sosial Berdasarkan konep-konsep Kunci ( Jakarta: Paramadina, 1996), h. 470.
Ijtihad adalah cara kerja nalar untuk menyelesaikan masalah-masalah yang berkaitan yang sulit untuk dipecahkan secara dengan naqliyah cara mengerahkan dan megoptimalkan pemikiran ketika tidak ditemukan nashnya secara eksplisit. Salah seorang sahabat Nabi yang dikenal sangat kreatif dan inovatif dalam menalar bahasa agama adalah Umar bin Khattab. Kreatifitas pemikiran Umar dalam menyelesaikan masalah dalam bahasa hukum disebut dengan ijtihad. Meski ijtihad dilakukan ketika tidak ditemukan secara jelas dalam al-Qur'an maupun hadis, namun justru ijtihadnya biasa bertentangan dengan teks laihiriah dan sunnah sehingga menyebabkan beberapa sahabat tidak sependapat demikian.

Dalam konteks tersebut, kreatiftas Umar memperihatkan dia sebagai seorang cendikiawan-filosof dan pemimpim yang bijak. Landasan ijtihad Umar dalam pendapat-pendapatnya yang kerap menimbulkan kontrovesri ini, betapa Umar telah mewariskan khazanah intelektual kepada generasi belakangan untuk tidak memahami agama secara rigid, kaku dan tekstual. Maka wajarlah jika Nabi pernah berandai-andai dengan menggambarkan sossok Umar yang sekiranya dirinya (Rasullullah) bukan yang dipilih menjadi Rasul, maka Umarlah yang pantas untuk menduduki posisi eebagai seorang Nabi

Dalam catatan sejarah dan beberapa riwayat menceritakan bahwa Umar dalam berbagai persoalan kemasayarakatan pada umumnya dan persoalan hukum pada khususnya, 
melakukan tindakan yang mengarah pada kemaslahatan kemanusiaan universal antara lain; melatakkan prinsip persamaan di depan hukum, melakukan ijtihad yang bertentangan dengan nash al-Qur;an dan sunnah seperti tidak membagi-bagikan harta rampasan perang yang pernah dicontohkan oleh Nabi yang juga secara tekstual disebutkan dalama al-Qur'an, tidak mempidakan bagi pencuri yang juga secara testual disebutkan di dalam alQur'an dan lain-lain. Ijtihad Umar ini tentu tidak bisa dibantah bahwa landasan berpikirnya ini memiliki substansi diturunkannya hukum adalah untuk kemaslahatan kemanusiaan universal yang sangat relevan dalam konteks kekinian.

\section{DAFTAR PUSTAKA}

Dawud, Abu. Sunan Abu Dawud ( tt. Dar al-fikr, t.th.

Djamil, Fathurrahman. Metode Ijtihad Majlis Tarjih Muhammadiyyah. Jakarta: Logos, 1995.

Hart, Michael H. Seratus Tokoh yang Paling Berpengaruh dalam Sejarah, terjemah H. Mahbub Djunaidi, Jakarta: Pustaka Jaya, 1987.

Husain, Haekal. Muhammad, al-Faruq Umar terjemah Ali Audah, Umar bin Khattab: Sebuah Telaah Mendalam Tentang Pertumbuhan Islam dan Kedaulatannya Masa itu
Surabaya: Litera AntarNusa, 2011.

Ma'arif, Ahmad Syafi'i. ( pengantar) dalam Fathurrahman Djamil, Metode ijtihad Majlis Tarjih Muhammadiyyah, Jakarta: Katalog dalamTerbitan, 1995),

Madjid, Nurcholish. Islam Doktrin dan Peradaban: Sebuah Telaah kritis Tentang Masalah Keimanan, Kemanusiaan dan Kemoderenan, Jakarta: Paramadina, 1992.

Madjid, Nurcholish. (editor) Khazanah Intelektual Islam, Jakarta: Bulan Bintang, 1994.

Nasution, Harun dan Azyumardi Azra (Ed), Perkembagan Modern dalam Islam, Jakarta: yayasan Obor Indonesia, 1985.

Nasution, Harun. Akal dan wahyu dalam Islam, Jakarta: UI Press, 1986.

Nasution, Harun." Ijtihad Sumber Ketiga Ajaran Islam", dalam Haidar Baqir, Ijtitihad dalam Sorotan, Bandung: Mizan, 1988.

Rahmat, Jalaluddin. (pengantar) dalamTaufik Adnan Amal, Islam dan Tantangan Modernitas: Studi atas Pemikiran Hukum Fazlur Rahman, Bandung: Mizan, 1989. 
Rais, Amin. ( Pengantar) dalam Fathurrahman Djamil, Metode Ijtihad Majlis Tarjih Muhammadiyyah, Jakarta: Logos, 1995.

Raharjo, Dawan Ensiklopedi Al-Qur'an: Tafsir Sosial Berdasarkan konepkonsep Kunci , Jakarta: Paramadina, 1996.

Shidik, Saifuddin. Ushul Fiqhi, Jakarata: PT Intermedia Ciptanusantara, 2009.

Syarif, Nadiyat. al-Ijtihad Fial-Islam, Beirtut: Mu'assasat al-Risalat,1981.

Team Pustaka Phoenix, Kamus Besar Bahasa Indonesia (Edisi Baru), Jakarta: Media Pustaka Phoenix, 2008.

Warson al-Munawwir, Ahmad. Kamus alMunawwir Arab-Indonesia Terlengkap. Yogyakarta: Pondok Pesantren al-munawwir, 1984. 